\title{
Stability evaluation of quail egg powder obtained by freeze-drying
}

\author{
Avaliação da estabilidade de ovo de codorna em pó obtidlo por liofillização \\ Evaluación de la estabilidad del huevo de codorniz en polvo obtenido por liofilización
}

Received: 09/22/2021 | Reviewed: 10/01/2021 | Accept: 10/28/2021| Published: 10/30/2021

\author{
Mariana Aparecida Nunes \\ ORCID: https://orcid.org/0000-0003-3003-8942 \\ Universidade Federal de Uberlândia, Brazil \\ E-mail: nana.ap.nunes@hotmail.com \\ Camila Alves Moreira \\ ORCID: https://orcid.org/0000-0001-7805-0575 \\ Universidade Federal de Uberlândia, Brazil \\ E-mail: camilamoreira13@hotmail.com \\ Lenilton Santos Soares \\ ORCID: https://orcid.org/0000-0002-5842-1209 \\ Universidade Federal de Lavras, Brazil \\ E-mail: lenilton.soares@ufla.br \\ Marta Fernanda Zotarelli \\ ORCID: https://orcid.org/0000-0002-1609-6866 \\ Universidade Federal de Uberlândia, Brazil \\ E-mail: martazotarelli@ufu.br \\ Marieli de Lima \\ ORCID: https://orcid.org/0000-0002-3731-4228 \\ Universidade Federal de Uberlândia, Brazil \\ E-mail:marieli@ufu.br
}

\begin{abstract}
This study aimed to produce quail egg powder by freeze-drying and to evaluate its stability in different types of flexible packages (low-density polyethylene, polypropylene and pigmented polypropylene) in high relative humidity (approximately $81 \%$ ) at $25{ }^{\circ} \mathrm{C}$ during 59 days. The packages were evaluated for water vapor permeability and freezedried egg was characterized as to bulk density and hygroscopicity (initial time), and moisture, water activity, $\mathrm{pH}$ and color (until the end of storage). GAB, BET and Peleg sorption isotherm models were adjusted to the experimental data to predict monolayer moisture content in the powdered eggs. The freeze-dried quail eggs presented a little oscillation in color coordinates, reduction in $\mathrm{pH}$, and increase in moisture content and water activity during storage for all packages used. No evaluated packaging was sufficiently effective as a moisture barrier. GAB and BET models fitted better to the experimental data for the freeze-dried quail egg, and the estimated monolayer moisture values were 0.0333 and 0.0227 $\mathrm{g} \mathrm{H}_{2} \mathrm{O} / \mathrm{g}$ solids, respectively. The powdered quail egg has industrial potential, however, it is susceptible to significant changes throughout storage when exposed to high relative humidity and conditioned in the tested packages. Commercially, as this product can be sold in regions with different temperatures and relative humidity, it is essential to consider the use of preservatives or anti-wetting agents.
\end{abstract}

Keywords: Poultry; Powdered egg; Storage; Package permeability.

\section{Resumo}

O objetivo deste estudo foi produzir ovo de codorna em pó através da liofilização e avaliar a sua estabilidade em diferentes tipos de embalagens flexíveis (polietileno de baixa densidade, polipropileno e polipropileno pigmentada) em alta umidade relativa (aproximadamente $81 \%$ ), a $25{ }^{\circ} \mathrm{C}$ durante 59 dias de armazenamento. As embalagens foram avaliadas quanto à permeabilidade ao vapor d'água e os ovos liofilizados foram analisados em relação à higroscopicidade e densidade aparente (tempo inicial), e $\mathrm{pH}$, umidade, atividade de água e cor (até o fim do armazenamento). Modelos de isotermas de sorção de GAB, BET e Peleg foram utilizados para a previsão da umidade na monocamada dos pós. Para todas as embalagens, o ovo de codorna liofilizado apresentou uma pequena oscilação nas coordenadas de cor, redução no $\mathrm{pH}$ e aumento de umidade e atividade de água ao longo do armazenamento. Nenhuma embalagem avaliada foi suficientemente eficaz como barreira à umidade. Os modelos de GAB e BET se ajustaram melhor aos dados experimentais para o ovo de codorna liofilizado e os valores estimados de umidade na monocamada foram de 0.0333 e $0.0227 \mathrm{~g} \mathrm{H}_{2} \mathrm{O} / \mathrm{g}$ sólidos, respectivamente. $\mathrm{O}$ ovo de codorna liofilizado possui potencial industrial, porém, é suscetível a alterações durante o armazenamento quando exposto a alta umidade relativa e acondicionado nas embalagens testadas. Comercialmente, como este produto pode ser vendido em regiões com diferentes temperaturas e umidades relativas, é fundamental considerar o uso de conservantes ou antiumectantes.

Palavras-chave: Aves; Ovo em pó; Armazenamento; Permeabilidade de embalagem. 


\section{Resumen}

El objetivo de este estudio fue producir huevo de codorniz en polvo mediante liofilización y evaluar su estabilidad en diferentes tipos de empaques flexibles (polietileno de baja densidad, polipropileno y polipropileno pigmentado) a alta humedad relativa (aproximadamente $81 \%$ ), a $25{ }^{\circ} \mathrm{C}$ durante 59 días de almacenamiento. Los empaques se evaluaron para determinar la permeabilidad al vapor de agua y los huevos liofilizados se analizaron para determinar su higroscopicidad y densidad aparente (tiempo inicial), y para determinar el $\mathrm{pH}$, la humedad, la actividad del agua y el color (hasta el final del almacenamiento). Se utilizaron modelos de isotermas de sorción de GAB, BET y Peleg para predecir la humedad en la monocapa de los polvos. Para todos los empaques, el huevo liofilizado mostró una ligera oscilación en las coordenadas de color, una reducción del pH y un aumento de la humedad y la actividad del agua durante el almacenamiento. Ningún empaque evaluado fue suficientemente eficaz como barrera contra la humedad. Los modelos GAB y BET se ajustan mejor a los datos experimentales para el huevo de codorniz liofilizado y los valores de humedad estimados en la monocapa fueron 0.0333 y $0.0227 \mathrm{~g} \mathrm{H}_{2} \mathrm{O} / \mathrm{g}$ sólidos, respectivamente. El huevo de codorniz liofilizado tiene potencial industrial, sin embargo, es susceptible a cambios durante el almacenamiento cuando se expone a alta humedad relativa y se almacena en los empaques probados. Comercialmente, como este producto puede venderse en regiones con diferentes temperaturas y humedad relativa, es fundamental considerar el uso de conservantes o agentes antihumectantes.

Palabras clave: Aves; Polvo de huevo; Almacenamiento; Permeabilidad del empaque.

\section{Introduction}

The quails are small birds (100-200 g, in adulthood) which belong to the Galliformes order and Phasianidae family, and the Coturnix genus is the most used for captive breeding worldwide, specially, Coturnix coturnix japonica (Japanese quail), that is the most common quail regarding egg production. The Japanese quail requires a relatively small breeding area, reaches sexual maturity early, has high egg-laying rate (about 300 eggs during your reproductive period), is resistant to disease, and easy to handle. Therefore, its breeding can be an excellent income-generating opportunity (Chełmońska et al., 2008; Shanaway, 1994; Thélie et al., 2019).

The quail egg performs an important role in human food due to its high nutritional potential, being a source of proteins, amino acids, minerals, and vitamins. Its composition is similar to the chicken egg (Arthur \& Bejaei, 2017; United States Department of Agriculture [USDA], 2021a; USDA, 2021b), however, the production and consumption of quail egg in the world are still very low compared to chicken eggs (Food and Agriculture Organization of the United Nations [FAO], 2021).

The quail egg weighs an average of $9 \mathrm{~g}$, approximately $1 / 5$ the weight of a medium chicken egg (USDA, 2021a; USDA, 2021b). Therefore, in several recipes the use of the quail egg becomes inconvenient. In addition to the small size, the greater fragility of the quail eggshell (Sun et al., 2019) is also an inconvenience, resulting in significant losses along the production chain.

The quail egg processing can be applied, offering convenience to consumers, in addition to promoting a longer shelf life, adding value to the product (Arthur \& Bejaei, 2017) and avoiding losses. A good example is the dehydration of the quail egg by freeze-drying, which is a mild method because it does not use high temperatures. In this process, the previously frozen food is subjected to a vacuum, and the present water changes directly from the solid state to steam (Jayaraman \& Gupta, 2006; Lechevalier et al., 2013; Sokhansanj \& Jayas, 2006). In addition to choosing a suitable dehydration method, it is essential that the powder produced is correctly stored to presents good stability throughout the storage period. Therefore, the choice of packaging is essential since it must protect the food from external factors, such as moisture and oxygen.

Considering that quail breeding can be a good source of income and given the small world production of quail eggs compared to chicken eggs, there must be an incentive for quail breeding and processing its eggs, which have great nutritional and industrial potential. However, there is a lack of literature about the production and characterization of quail egg powder. In this way, further studies about the processing, stability and packaging of powdered quail eggs must be developed, promoting a new world trend.

Several studies have already been developed to evaluate the interference of packaging on the stability of powdered 
foods, such as apple peel (Henríquez et al., 2013), macaúba palm (Oliveira et al., 2015) and sweetened yogurt (Seth et al., 2018) throughout storage. Moura et al. (2008) evaluated the effects of different packages on the internal quality of fresh Japanese quail eggs. However, concerning the quail egg powder, there is no still publication with this same purpose.

This study aimed to produce quail egg powder by freeze-drying, to characterize and evaluate its stability in different types of flexible packages (low-density polyethylene, polypropylene and pigmented polypropylene) in high relative humidity (approximately 81\%), during 59 days.

\section{Methodology}

The present study consists of experimental, applied and quantitative research (Gil, 2008; Köche, 2011; Pereira et al., 2018). Methodological support was provided by the third, fourth and fifth authors. All experiments were carried out in the laboratories of the Food Engineering course, at the Federal University of Uberlândia, campus Patos de Minas, MG, Brazil. As this is a quantitative research, the experimental data were treated statistically, as detailed in item 2.8 .

\subsection{Obtaining and preparing eggs}

The Japanese quail eggs (Coturnix coturnix japonica) were obtained in the local market. For the production of powdered quail eggs, first, they were broken, homogenized and filtered, to remove fragments of shells, chalazae, and membranes. After homogenization, the samples were pasteurized in an Ultratermostatic Bath SL - 152/18 (Solab, Piracicaba, SP), at a temperature of $60^{\circ} \mathrm{C}$ for $3.5 \mathrm{~min}$.

\subsection{Moisture of liquid egg}

The moisture of the liquid quail egg was determined by the gravimetric method, using an oven with forced air circulation model Q314M252 (Quimis, Diadema, SP), at $60^{\circ} \mathrm{C}$ for $72 \mathrm{~h}$ (adapted of Vilela et al., 2016). Three replicates and three repetitions were performed.

\subsection{Freeze-drying}

After pasteurization, the samples were frozen in an Ultra Freezer CL 520-86V (ColdLab, Piracicaba, SP) at $-80^{\circ} \mathrm{C}$ for a minimum period of $12 \mathrm{~h}$. In sequence, the samples were freeze-dried in a freeze dryer L101- Liotop® (Liobras, São Carlos, $\mathrm{SP})$ for $24 \mathrm{~h}$, and then, defragmented using a domestic mixer to obtain the powder.

For packaging powders, low-density polyethylene (LDPE), polypropylene (PP) and pigmented polypropylene (P-PP) packages were used, all with an area of $0.64 \mathrm{~m}^{2}$ and thicknesses of $70.00 \pm 1.8 \mu \mathrm{m}, 63.00 \pm 0.94 \mu \mathrm{m}$ and $46.16 \pm 0.23 \mu \mathrm{m}$, respectively, acquired in the local market.

\subsection{Powder characterization after freeze-drying}

The egg powder was characterized as moisture, bulk density, and hygroscopicity. The moisture was determined by the gravimetric method, as previously mentioned (item 2.2), until constant weight. The bulk density was determined by mass ratio to the volume, expressed in $\mathrm{g} / \mathrm{cm}^{3}$. The hygroscopicity was measured according to Tonon et al. (2008), to the unpacked egg powder and egg powder packaged in LDPE, PP and PP-P packages. The samples were weighed, disposed in a desiccator at 25 ${ }^{\circ} \mathrm{C}$ and relative humidity (RH) of approximately $75 \%$, conditioned by $\mathrm{NaCl}$ saturated solution and weighed again after 7 days. The hygroscopicity of the powders was expressed as a percentage of water adsorbed by the mass of dry solids. All of these analyzes were performed in three repetitions. 


\subsection{Water vapor permeability of packages}

The LDPE, PP, and PP-P packages were evaluated for water vapor permeability (WVP), as Ortiz et al. (2017) performed, with modifications. The packages were placed in stainless steel capsules, sealed with rubber rings and screws, with an internal relative humidity of $2 \%$, conditioned by the presence of dry $\mathrm{CaCl}_{2}$. The whole set was stored in a desiccator with $75 \% \mathrm{RH}$, conditioned by $\mathrm{NaCl}$ saturated solution at $25{ }^{\circ} \mathrm{C}$. The capsules were weighed for 7 days, at $24 \mathrm{~h}$ intervals. For this analysis, two repetitions were performed. WVP was calculated using Equation (1).

$$
W V P=\frac{K \times t}{A \times P \times\left(R H_{1}-R H_{2}\right)}
$$

Where: WVP = water vapor permeability $\left(\mathrm{g} . \mu \mathrm{m} / \mathrm{m}^{2} . \mathrm{h} . \mathrm{Pa}\right) ; \mathrm{K}=$ water vapor permeability rate $(\mathrm{g} / \mathrm{h}) ; \mathrm{t}=$ thickness $(\mu \mathrm{m}) ; \mathrm{A}=$ permeation area $\left(\mathrm{m}^{2}\right), \mathrm{P}=$ water vapor pressure at $25^{\circ} \mathrm{C}(\mathrm{Pa}) ; \mathrm{RH}_{1}=$ equilibrium relative humidity/water activity outside the capsule; $\mathrm{RH}_{2}=$ equilibrium relative humidity/water activity inside the capsule. The permeation rate $(\mathrm{K})$ was found from linear regression of the water gain data plotted by time, corresponding to the slope of the line.

\subsection{Powder characterization during storage}

Powders were evaluated during storage as moisture, water activity, $\mathrm{pH}$ and color. For this, samples of $3 \mathrm{~g}$ were placed in different packages. The LDPE and PP packages were sealed by heating in a sealer model M-300T (Barbi, Itu, SP). At the same time, the PP-P already had its adhesive layer for sealing due to its limitation concerning sealing by high temperature. All were stored for 59 days in BOD TE-371 (Tecnal, Piracicaba, SP) at $25{ }^{\circ} \mathrm{C}$, with $80.99 \pm 0.28 \% \mathrm{RH}$, obtained by $\left(\mathrm{NH}_{4}\right)_{2} \mathrm{SO}_{4}$ saturated solution (Greenspan, 1977).

\subsubsection{Water activity and moisture analysis}

The water activity was obtained by reading directly on the AquaLab LITE equipment (Decagon Devices, São José dos Campos, SP). The moisture was determined by the gravimetric method, as previously mentioned (item 2.2). Three repetitions were performed for both analysis.

\subsection{2 $\mathrm{pH}$ analysis}

The $\mathrm{pH}$ was determined by a pHmeter model mPA-210 (MS Tecnopon, Piracicaba, SP) previously calibrated, after diluting the powder in distilled water in a proportion of 1:10 (w/v) (Instituto Adolfo Lutz, 2008). Three repetitions were performed.

\subsubsection{Color profile}

The color of the powders was determined by a Konica Minolta CR-400 colorimeter (Konica Minolta, Ramsey, NJ) with a viewing angle of $0^{\circ}$ and illuminant $C$, previously calibrated. The colors, measured on the CIE $\mathrm{L}^{*} \mathrm{a}^{*} \mathrm{~b}^{*}$ scale, were expressed in terms of luminosity $\left(L^{*}=0\right.$ : black and $L^{*}=100$ : white) and chromaticity $\left(-a^{*}=\right.$ green and $+a^{*}=$ red; $-b^{*}=$ blue and $+b^{*}=$ yellow). The global color change $\left(\Delta \mathrm{E}^{*}\right)$ was calculated to express the overall color difference of the samples during the storage period (in relation to the day 0), defined by Equation 2. Three repetitions were performed.

$$
\Delta E^{*}=\sqrt{\left(\Delta L^{*}\right)^{2}+\left(\Delta a^{*}\right)^{2}+\left(\Delta b^{*}\right)^{2}}
$$




\subsection{Sorption isotherms}

The sorption isotherms were determined by the static gravimetric method at $25^{\circ} \mathrm{C}$. Eight saturated saline solutions were prepared: $\mathrm{LiCl}, \mathrm{CH}_{3} \mathrm{COOK}, \mathrm{K}_{2} \mathrm{CO}_{3}, \mathrm{Mg}\left(\mathrm{NO}_{3}\right)_{2}, \mathrm{KI}, \mathrm{NaCl}, \mathrm{KCl}$ and $\mathrm{BaCl}_{2}$, for approximate values of relative humidity of $11.3 \%$, $22.6 \%, 43.2 \%, 52.9 \%, 68.9 \%, 75.3 \%, 84.3 \%$ and 90.2\%, respectively (Dufour et al., 1996; Greenspan, 1977). For each of the relative humidity, $1 \mathrm{~g}$ of freeze-dried quail egg was used. The samples were weighed at regular intervals until they reached equilibrium. The mathematical models of GAB, BET, and Peleg, shown in Table 1, were adjusted to experimental data. The routine program was performed by the software Matlab R2013a ${ }^{\circledR}$ (Mathworks Inc., USA). For each saline solution, three repetitions were performed.

Table 1. Mathematical models used for adjustment of the experimental data for freeze-dried quail egg.

\begin{tabular}{cc}
\hline Model & $X=\frac{\text { Equation }}{[(1-K a w)(1-K a w+C K a w)]}$ \\
GAB & $X=\frac{X_{m} C K a w}{[(1-a w)(1+(C-1) a w)]}$ \\
Peleg & $X=K_{1} a w^{n 1}+K_{2} a w^{n 2}$ \\
\hline
\end{tabular}

$\mathrm{X}$ is the equilibrium water content (dry basis), $\mathrm{X}_{\mathrm{m}}$ is the monolayer water content (dry basis), aw is water activity, $\mathrm{C}$ e $\mathrm{K}$ are model constants and $\mathrm{K}_{1}, \mathrm{~K}_{2}, \mathrm{n}_{1}$ and $\mathrm{n}_{2}$ are model parameters estimated using non-linear regression by Matlab software. Source: Modified from Conceição et al. (2016).

\subsection{Statistical analysis}

The influence of the storage time and the material used in the packaging of the quail egg powder was evaluated through analysis of variance (ANOVA) and mean comparison test (Tukey) at 95\% confidence level, using the Statistica 7.0 software (StatSoft Inc, Tulsa, OK, USA). The results will be presented as mean \pm standard deviation (SD).

\section{Results and Discussion}

\subsection{Moisture of liquid and powdered egg}

The liquid quail egg moisture obtained in the present study was $73.12 \%( \pm 0.91)$, a value close to $74.35 \%$, provided in the quail egg composition table of the USDA (2021a). After freeze-drying, the egg presented moisture of $1.56 \%$ ( \pm 0.78 ), a value close to that obtained by Velioğlu (2019), which was $2 \%$ for freeze-dried whole quail egg. Koç et al. (2011a) produced powdered whole chicken egg by spray-drying at an inlet temperature of $171.8^{\circ} \mathrm{C}$ and reported a $2.02 \%$ of moisture after drying.

\subsection{Bulk density}

Bulk density is directly associated with the transport and storage capacity, as it expresses the volume occupied per unit of mass of powder (Fitzpatrick, 2013). The bulk density of the powdered quail egg was $0.299 \mathrm{~g} / \mathrm{cm}^{3}( \pm 0.009)$, close to the value obtained by Koç et al. (2011a), which was $0.305 \mathrm{~g} / \mathrm{cm}^{3}$ for spray-dried chicken egg powder.

\subsection{Water vapor permeability of packages and powder hygroscopicity}

Table 2 shows the results of water vapor permeability of packages and powder hygroscopicity. 
Table 2. Hygroscopicity of freeze-dried quail egg, water vapor permeability rate (K), and water vapor permeability (WVP) of packages.

\begin{tabular}{cccc}
\hline Packaging material & Higroscopicity $(\%)$ & $K(\mathrm{~g} / \mathrm{h})$ & WVP $\left(\mathrm{g} \cdot \mu \mathrm{m} / \mathrm{m}^{2} . \mathrm{h} . P a\right)$ \\
\hline No packaged & $8.46 \pm 0.102^{\mathrm{a}}$ & - & - \\
PP-P & $2.62 \pm 0.712^{\mathrm{b}}$ & $0.00009^{\mathrm{a}}$ & $2.81 \times 10^{-8 \mathrm{a}}$ \\
LDPE & $3.50 \pm 0.043^{\mathrm{b}}$ & $0.0004^{\mathrm{b}}$ & $1.90 \times 10^{-7 \mathrm{~b}}$ \\
PP & $3.30 \pm 0.081^{\mathrm{b}}$ & $0.0004^{\mathrm{b}}$ & $1.71 \times 10^{-7 \mathrm{~b}}$ \\
\hline
\end{tabular}

Values with different lowercase letters in the same column differ statistically $(\mathrm{p}<0.05)$; PPP: pigmented polypropylene, LDPE: low-density polyethylene, PP: polypropylene. Source: Authors (2021).

The moisture gain by a hygroscopic powder can considerably damage its technological properties (Henríquez et al., 2013). Therefore, powdered foods must be stored in packages that offer proper protection against the water passage.

All packages performed a barrier role, significantly reducing water absorption with no difference concerning the materials used in packaging. Despite the lower water vapor permeability of the PP-P package compared to the others, it was not sufficient to promote a significant difference in hygroscopicity.

Koç et al. (2011a) found a hygroscopicity value of approximately $5 \%$ for the unpackaged powdered whole chicken egg, produced by spray-drying, exposed for 90 minutes to an atmosphere of $75.3 \% \mathrm{RH}$ at $25{ }^{\circ} \mathrm{C}$. According to these authors, the highest absorption of moisture occurred in this interval.

\subsection{Powder characterization during storage}

\subsubsection{Water activity and moisture analysis}

Tables 3 and 4 show the results of water activity and moisture, respectively, for powdered quail eggs for the three packages during storage.

Table 3. Water activity of freeze-dried quail eggs during storage at a $25{ }^{\circ} \mathrm{C}$ and $\sim 81 \% \mathrm{RH}$.

\begin{tabular}{cccc}
\hline \multirow{2}{*}{ Period (days) } & \multicolumn{3}{c}{ Water activity } \\
\cline { 2 - 4 } & PP-P & LDPE & PP \\
\hline 0 & $0.191 \pm 0,010^{\mathrm{a}, \mathrm{A}}$ & $0.191 \pm 0,010^{\mathrm{a}, \mathrm{A}}$ & $0.191 \pm 0,010^{\mathrm{a}, \mathrm{A}}$ \\
7 & $0.427 \pm 0,098^{\mathrm{b}, \mathrm{A}}$ & $0.423 \pm 0,008^{\mathrm{b}, \mathrm{A}}$ & $0.421 \pm 0,013^{\mathrm{b}, \mathrm{A}}$ \\
17 & $0.610 \pm 0,022^{\mathrm{c}, \mathrm{A}}$ & $0.542 \pm 0,015^{\mathrm{c}, \mathrm{B}}$ & $0.511 \pm 0,020^{\mathrm{c}, \mathrm{B}}$ \\
24 & $0.539 \pm 0,097^{\mathrm{c}, \mathrm{b}, \mathrm{A}}$ & $0.614 \pm 0,007^{\mathrm{d}, \mathrm{A}}$ & $0.588 \pm 0,012^{\mathrm{f}, \mathrm{A}}$ \\
31 & $0.545 \pm 0,074^{\mathrm{c}, \mathrm{b}, \mathrm{A}}$ & $0.645 \pm 0,012^{\mathrm{f}, \mathrm{A}}$ & $0.614 \pm 0,016^{\mathrm{e}, \mathrm{f}, \mathrm{A}}$ \\
38 & $0.620 \pm 0,060^{\mathrm{c}, \mathrm{A}}$ & $0.668 \pm 0,005^{\mathrm{f,g}, \mathrm{A}}$ & $0.642 \pm 0,001^{\mathrm{e}, \mathrm{A}}$ \\
45 & $0.593 \pm 0,066^{\mathrm{c}, \mathrm{b}, \mathrm{A}}$ & $0.648 \pm 0,005^{\mathrm{f}, \mathrm{A}}$ & $0.640 \pm 0,004^{\mathrm{e}, \mathrm{A}}$ \\
52 & $0.695 \pm 0,012^{\mathrm{c}, \mathrm{A}}$ & $0.687 \pm 0,006^{\mathrm{g}, \mathrm{A}}$ & $0.658 \pm 0,039^{\mathrm{e}, \mathrm{A}}$ \\
59 & $0.711 \pm 0,033^{\mathrm{c}, \mathrm{A}}$ & $0.722 \pm 0,009^{\mathrm{e}, \mathrm{A}}$ & $0.719 \pm 0,007^{\mathrm{d}, \mathrm{A}}$ \\
\hline
\end{tabular}

Values with different lowercase letters in the same column differ statistically $(\mathrm{p}<0.05)$. Values with different uppercase letters in the same row differ statistically $(\mathrm{p}<0.05)$. P-PP: pigmented polypropylene, LDPE: low-density polyethylene, PP: polypropylene.

Source: Authors (2021). 
Table 4. Moisture (wet basis) of freeze-dried quail eggs during storage at a $25^{\circ} \mathrm{C}$ and $\sim 81 \% \mathrm{RH}$.

\begin{tabular}{|c|c|c|c|}
\hline \multirow{2}{*}{ Period (days) } & \multicolumn{3}{|c|}{ Moisture (\%) } \\
\hline & P-PP & LDPE & PP \\
\hline 0 & $1.56 \pm 0.080^{\mathrm{a}, \mathrm{A}}$ & $1.56 \pm 0.080^{\mathrm{a}, \mathrm{A}}$ & $1.56 \pm 0.080^{\mathrm{a}, \mathrm{A}}$ \\
\hline 7 & $3.00 \pm 0.651^{\mathrm{b}, \mathrm{A}}$ & $3.18 \pm 0.178^{\mathrm{b}, \mathrm{A}}$ & $3.77 \pm 0.508^{\mathrm{b}, \mathrm{A}}$ \\
\hline 17 & $6.68 \pm 0.019^{\mathrm{c}, \mathrm{d}, \mathrm{A}}$ & $5.83 \pm 0.046^{\mathrm{c}, \mathrm{B}}$ & $5.67 \pm 0.503^{\mathrm{c}, \mathrm{B}}$ \\
\hline 24 & $4.14 \pm 0.392^{\mathrm{b}, \mathrm{A}}$ & $6.55 \pm 0.536^{\mathrm{c}, \mathrm{d}, \mathrm{B}}$ & $5.48 \pm 0.335^{\mathrm{c}, \mathrm{B}}$ \\
\hline 31 & $6.11 \pm 0.874^{\mathrm{c}, \mathrm{A}}$ & $7.77 \pm 0.554^{\mathrm{e}, \mathrm{f}, \mathrm{B}}$ & $7.05 \pm 0.232^{\mathrm{d}, \mathrm{A}, \mathrm{B}}$ \\
\hline 38 & $6.98 \pm 0.349^{\mathrm{c}, \mathrm{d}, \mathrm{e}, \mathrm{A}}$ & $7.22 \pm 0.188^{\mathrm{d}, \mathrm{e}, \mathrm{A}}$ & $7.02 \pm 0.106^{\mathrm{d}, \mathrm{A}}$ \\
\hline 45 & $7.63 \pm 0.209^{\mathrm{d}, \mathrm{e}, \mathrm{A}}$ & $7.69 \pm 0.381^{\mathrm{e}, \mathrm{f}, \mathrm{A}}$ & $7.10 \pm 0.539^{\mathrm{d}, \mathrm{A}}$ \\
\hline 52 & $9.03 \pm 0.537^{\mathrm{f}, \mathrm{A}}$ & $7.98 \pm 0.258^{\mathrm{e}, \mathrm{f}, \mathrm{B}}$ & $8.09 \pm 0.415^{\mathrm{d}, \mathrm{A}, \mathrm{B}}$ \\
\hline 59 & $8.12 \pm 0.140^{\mathrm{f}, \mathrm{A}}$ & $8.29 \pm 0.314^{\mathrm{f}, \mathrm{A}}$ & $7.59 \pm 0.380^{\mathrm{d}, \mathrm{A}}$ \\
\hline
\end{tabular}

Values with different lowercase letters in the same column differ statistically $(\mathrm{p}<0.05)$. Values with different uppercase letters in the same row differ statistically $(\mathrm{p}<0.05)$. P-PP: pigmented polypropylene, LDPE: low-density polyethylene, PP: polypropylene.

Source: Authors (2021).

Throughout the storage period, there was a significant increasing in water activity and moisture in powders for all packages, limiting their shelf lives. Maximum moisture of $5 \%(\mathrm{w} / \mathrm{w})$ and water activity until 0.3 are generally quality requirements for dried foods intended for commercialization, since under these conditions, microbial growth and undesirable reactions are avoided (Henríquez et al., 2013; Sangamithra et al., 2014). The water activity and moisture values were already above these limits on the 7th and 17th day of storage, respectively. Therefore, despite being water barriers, the packaging used were not sufficient to guarantee the stability of the powdered egg totally during storage, under the established conditions of relative humidity and temperature.

It is also important to note that quail eggs did not have any additives to help extend their shelf life. Furthermore, because they are a product rich in nutrients and with low humidity and water activity, the potential gradient of moisture adsorption is high when subjected to a high RH, as in this study. Commercially, as this product can be sold in regions with different temperatures and $\mathrm{RH}$, it is essential to consider the use of preservatives or anti-wetting agents.

In some periods, it was possible to notice that the type of packaging influenced the moisture gain by the powders. However, on the last day of storage, there was no significant difference between the moisture values of the different samples.

Several authors also reported increased moisture and water activity in powder products stored in different packaging materials during storage (Koç et al., 2011a; Oliveira et al., 2015; Udomkun et al., 2016). Seth et al. (2018) reported an increase from $4.85 \%$ to almost $9 \%$ moisture (dry basis) for powdered sweetened yogurt (spray-dried), stored in LDPE package for 49 days at $38 \pm 1{ }^{\circ} \mathrm{C}$ and $90 \%$ RH. On the other hand, Raitio et al. (2011) evaluated the stability of cauliflower soup powder, prepared with rapeseed oil and different antioxidants (rosemary extract, carnosic acid, citric acid, tocopherols extract and ascorbyl palmitate), during 12 weeks of storage at $40{ }^{\circ} \mathrm{C}$ and $75 \% \mathrm{RH}$, in polypropylene package, and reported no gain for moisture and observed small increase (approximately 0.1 ) for water activity, for all the samples of powders.

Koç et al. (2011a) reported a slight increase of approximately 0.05 in the water activity and 0,5\% in the moisture of powdered whole chicken egg, produced by spray-drying, in 180 days, with small oscillations during this period. However, the powders were stored in 50\% RH, lower than used in this study, and packaged in aluminum laminated polyethylene pouches. 


\subsection{2 pH analysis}

Table 5 shows the results of $\mathrm{pH}$ values for powdered quail eggs for the three packages during storage.

Table 5. $\mathrm{pH}$ values of freeze-dried quail egg during storage at a $25{ }^{\circ} \mathrm{C}$ and $\sim 81 \% \mathrm{RH}$.

\begin{tabular}{cccc}
\hline \multirow{2}{*}{ Period (days) } & \multicolumn{3}{c}{$\mathrm{pH}$} \\
\cline { 2 - 4 } & $\mathrm{P}-\mathrm{PP}$ & $\mathrm{LDPE}$ & $\mathrm{PP}$ \\
\hline 0 & $9.11 \pm 0.010^{\mathrm{a}, \mathrm{A}}$ & $9.11 \pm 0.010^{\mathrm{a}, \mathrm{A}}$ & $9.11 \pm 0.010^{\mathrm{a}, \mathrm{A}}$ \\
7 & $8.85 \pm 0.006^{\mathrm{b}, \mathrm{A}}$ & $8.86 \pm 0.000^{\mathrm{b}, \mathrm{A}}$ & $8.85 \pm 0.031^{\mathrm{b}, \mathrm{A}}$ \\
17 & $8.78 \pm 0.025^{\mathrm{bd}, \mathrm{A}}$ & $8.84 \pm 0.031^{\mathrm{b}, \mathrm{A}}$ & $8.83 \pm 0.015^{\mathrm{b}, \mathrm{A}}$ \\
24 & $8.87 \pm 0.056^{\mathrm{b}, \mathrm{A}}$ & $8.83 \pm 0.061^{\mathrm{b}, \mathrm{A}}$ & $8.84 \pm 0.021^{\mathrm{b}, \mathrm{A}}$ \\
31 & $8.62 \pm 0.135^{\mathrm{b}, \mathrm{c}, \mathrm{A}}$ & $8.57 \pm 0.032^{\mathrm{c}, \mathrm{A}}$ & $8.61 \pm 0.006^{\mathrm{c}, \mathrm{A}}$ \\
38 & $8.43 \pm 0.070^{\mathrm{c}, \mathrm{A}}$ & $8.42 \pm 0.012^{\mathrm{d}, \mathrm{A}}$ & $8.46 \pm 0.040^{\mathrm{d}, \mathrm{A}}$ \\
45 & $8.44 \pm 0.134^{\mathrm{c}, \mathrm{A}}$ & $8.30 \pm 0.067^{\mathrm{e}, \mathrm{A}}$ & $8.26 \pm 0.021^{\mathrm{e}, \mathrm{A}}$ \\
52 & $8.17 \pm 0.036^{\mathrm{d}, \mathrm{A}}$ & $8.30 \pm 0.015^{\mathrm{e}, \mathrm{B}}$ & $8.17 \pm 0.036^{\mathrm{f}, \mathrm{A}}$ \\
59 & $8.16 \pm 0.160^{\mathrm{d}, \mathrm{A}}$ & $8.10 \pm 0.062^{\mathrm{f}, \mathrm{A}}$ & $8.19 \pm 0.026^{\mathrm{e}, \mathrm{f}, \mathrm{A}}$ \\
\hline
\end{tabular}

Values with different lowercase letters in the same column differ statistically $(\mathrm{p}<$ 0.05). Values with different uppercase letters in the same row differ statistically ( $\mathrm{p}<$ 0.05). P-PP: pigmented polypropylene, LDPE: low-density polyethylene, PP: polypropylene.

Source: Authors (2021).

Powdered eggs, packaged in the three types of packages, showed a significant reduction in the $\mathrm{pH}$ value during storage. However, the packaging material did not affect the $\mathrm{pH}$ profiles of the eggs, except for the 52nd day, where the $\mathrm{pH}$ of the egg packaged in the LDPE package was higher than the others.

One of the reasons for this drop in $\mathrm{pH}$ during storage, which was accompanied by the moisture gain of the powders, may have been the action of lipolytic enzymes, which promote the release of free fatty acids and phosphoric acid, and proteolytic enzymes, with the release of amino acids (Lieu et al., 1978). Another possibility is transforming of basic amines into less basic structures, and the formation of acids from the degradation of sugars in the Maillard reactions (Beck et al., 1990; Martins et al., 2001).

Although there are no recent studies that evaluate the $\mathrm{pH}$ of egg powder over storage, a similar behavior to that found in this study was reported by Lieu et al. (1978), that observed a reduction in the $\mathrm{pH}$ of powdered chicken egg (initial moisture of $5 \%$ ) vacuum packed in PVC plastic bags, wrapped in aluminum foil, from 8.6 to 7.7 in 6 months of storage at $23.9^{\circ} \mathrm{C}$. The storage relative humidity was not specified by the authors.

\subsubsection{Color profile}

Table 6 shows the color coordinates for powdered quail eggs for the three packages during storage. 
Table 6. Color coordinates ( $\mathrm{L}^{*}, \mathrm{a}^{*}$ and $\mathrm{b}^{*}$ ) of freeze-dried quail eggs during storage at $25^{\circ} \mathrm{C}$ and $\sim 81 \% \mathrm{RH}$.

\begin{tabular}{|c|c|c|c|}
\hline \multicolumn{4}{|c|}{$\mathrm{L}^{*}$} \\
\hline Period (days) & PP-P & LDPE & $\mathrm{PP}$ \\
\hline 0 & $34.66 \pm 1.167^{\mathrm{a}, \mathrm{b}, \mathrm{c}, \mathrm{A}}$ & $34.66 \pm 1.167^{\mathrm{a}, \mathrm{b}, \mathrm{A}}$ & $34.66 \pm 1.167^{\mathrm{a}, \mathrm{b}, \mathrm{A}}$ \\
\hline 7 & $30.93 \pm 0.805^{\mathrm{a}, \mathrm{A}}$ & $32.29 \pm 0.520^{\mathrm{a}, \mathrm{A}}$ & $32.64 \pm 2.096^{\mathrm{a}, \mathrm{A}}$ \\
\hline 17 & $33.30 \pm 1.802^{\mathrm{a}, \mathrm{b}, \mathrm{c}, \mathrm{A}}$ & $33.63 \pm 0.728^{\mathrm{a}, \mathrm{A}}$ & $33.21 \pm 1.175^{\mathrm{a}, \mathrm{A}}$ \\
\hline 24 & $33.61 \pm 1.295^{\mathrm{a}, \mathrm{b}, \mathrm{c}, \mathrm{A}}$ & $32.46 \pm 2.597^{\mathrm{a}, \mathrm{A}}$ & $33.06 \pm 1.361^{\mathrm{a}, \mathrm{A}}$ \\
\hline 31 & $33.55 \pm 0.119^{\mathrm{a}, \mathrm{b}, \mathrm{c}, \mathrm{A}}$ & $32.13 \pm 1.808^{\mathrm{a}, \mathrm{A}}$ & $33.48 \pm 1.297^{\mathrm{a}, \mathrm{A}}$ \\
\hline 38 & $36.01 \pm 3.745^{\mathrm{b}, \mathrm{c}, \mathrm{A}}$ & $32.41 \pm 1.244^{\mathrm{a}, \mathrm{A}}$ & $33.64 \pm 2.417^{\mathrm{a}, \mathrm{A}}$ \\
\hline 45 & $34.52 \pm 1.550^{\mathrm{a}, \mathrm{b}, \mathrm{c}, \mathrm{A}}$ & $32.58 \pm 0.958^{\mathrm{a}, \mathrm{A}}$ & $32.70 \pm 2.150^{\mathrm{a}, \mathrm{A}}$ \\
\hline 52 & $33.08 \pm 1.595^{\mathrm{a}, \mathrm{b}, \mathrm{A}}$ & $33.92 \pm 0.810^{\mathrm{a}, \mathrm{A}}$ & $32.46 \pm 1.290^{\mathrm{a}, \mathrm{A}}$ \\
\hline 59 & $38.07 \pm 0.909^{\mathrm{c}, \mathrm{A}}$ & $38.02 \pm 1.750^{\mathrm{b}, \mathrm{A}}$ & $38.99 \pm 0.263^{\mathrm{b}, \mathrm{A}}$ \\
\hline \multicolumn{4}{|c|}{$a^{*}$} \\
\hline Period (days) & PP-P & LDPE & $\mathrm{PP}$ \\
\hline 0 & $1.21 \pm 0.155^{\mathrm{a}, \mathrm{A}}$ & $1.21 \pm 0.155^{\mathrm{a}, \mathrm{b}, \mathrm{c}, \mathrm{A}}$ & $1.21 \pm 0.155^{\mathrm{a}, \mathrm{b}, \mathrm{A}}$ \\
\hline 7 & $0.49 \pm 0.251^{\mathrm{b}, \mathrm{A}}$ & $0.81 \pm 0.241^{\mathrm{a}, \mathrm{A}}$ & $0.89 \pm 0.384^{\mathrm{b}, \mathrm{A}}$ \\
\hline 17 & $1.16 \pm 0.250^{\mathrm{a}, \mathrm{A}}$ & $0.96 \pm 0.067^{\mathrm{a}, \mathrm{b}, \mathrm{A}}$ & $1.05 \pm 0.117^{\mathrm{a}, \mathrm{b}, \mathrm{A}}$ \\
\hline 24 & $1.08 \pm 0.240^{\mathrm{a}, \mathrm{b}, \mathrm{A}}$ & $1.26 \pm 0.020^{\mathrm{a}, \mathrm{b}, \mathrm{c}, \mathrm{A}}$ & $1.05 \pm 0.151^{\mathrm{a}, \mathrm{b}, \mathrm{A}}$ \\
\hline 31 & $1.36 \pm 0.269^{\mathrm{a}, \mathrm{A}}$ & $1.31 \pm 0.466^{\mathrm{a}, \mathrm{b}, \mathrm{c}, \mathrm{A}}$ & $1.45 \pm 0.086^{\mathrm{a}, \mathrm{b}, \mathrm{A}}$ \\
\hline 38 & $1.46 \pm 0.155^{\mathrm{a}, \mathrm{A}}$ & $1.58 \pm 0.291^{\mathrm{b}, \mathrm{c}, \mathrm{A}}$ & $1.40 \pm 0.271^{\mathrm{a}, \mathrm{b}, \mathrm{A}}$ \\
\hline 45 & $1.13 \pm 0.021^{\mathrm{a}, \mathrm{A}}$ & $1.34 \pm 0.156^{\mathrm{a}, \mathrm{b}, \mathrm{c}, \mathrm{A}, \mathrm{B}}$ & $1.58 \pm 0.255^{\mathrm{a}, \mathrm{B}}$ \\
\hline 52 & $1.48 \pm 0.270^{\mathrm{a}, \mathrm{A}}$ & $1.40 \pm 0.127^{\mathrm{a}, \mathrm{b}, \mathrm{c}, \mathrm{A}}$ & $1.56 \pm 0.197^{\mathrm{a}, \mathrm{A}}$ \\
\hline 59 & $1.46 \pm 0.130^{\mathrm{a}, \mathrm{A}}$ & $1.84 \pm 0.143^{\mathrm{c}, \mathrm{A}}$ & $1.40 \pm 0.249^{\mathrm{a}, \mathrm{b}, \mathrm{A}}$ \\
\hline \multicolumn{4}{|c|}{$b^{*}$} \\
\hline Period (days) & PP-P & LDPE & $\mathrm{PP}$ \\
\hline 0 & $20.22 \pm 0.419^{\mathrm{a}, \mathrm{b}, \mathrm{A}}$ & $20.22 \pm 0.419^{\mathrm{a}, \mathrm{A}}$ & $20.22 \pm 0.419^{\mathrm{a}, \mathrm{b}, \mathrm{A}}$ \\
\hline 7 & $18.52 \pm 0.921^{\mathrm{a}, \mathrm{A}}$ & $18.74 \pm 0.151^{\mathrm{a}, \mathrm{A}}$ & $19.28 \pm 0.724^{\mathrm{a}, \mathrm{A}}$ \\
\hline 17 & $20.06 \pm 0.638^{\mathrm{a}, \mathrm{b}, \mathrm{A}}$ & $19.10 \pm 0.564^{\mathrm{a}, \mathrm{A}}$ & $19.33 \pm 0.405^{\mathrm{a}, \mathrm{A}}$ \\
\hline 24 & $19.99 \pm 1.140^{\mathrm{a}, \mathrm{b}, \mathrm{A}}$ & $19.26 \pm 1.501^{\mathrm{a}, \mathrm{A}}$ & $19.74 \pm 0.613^{\mathrm{a}, \mathrm{b}, \mathrm{A}}$ \\
\hline 31 & $19.89 \pm 0.729^{\mathrm{a}, \mathrm{b}, \mathrm{A}}$ & $19.75 \pm 1.170^{\mathrm{a}, \mathrm{A}}$ & $20.25 \pm 0.284^{\mathrm{a}, \mathrm{b}, \mathrm{A}}$ \\
\hline 38 & $18.28 \pm 1.220^{\mathrm{a}, \mathrm{A}}$ & $20.18 \pm 1.082^{\mathrm{a}, \mathrm{A}}$ & $20.00 \pm 1.086^{\mathrm{a}, \mathrm{b}, \mathrm{A}}$ \\
\hline 45 & $19.51 \pm 0.260^{\mathrm{a}, \mathrm{b}, \mathrm{A}}$ & $19.98 \pm 0.532^{\mathrm{a}, \mathrm{A}}$ & $20.30 \pm 0.667^{\mathrm{a}, \mathrm{b}, \mathrm{A}}$ \\
\hline 52 & $20.19 \pm 0.419^{\mathrm{a}, \mathrm{b}, \mathrm{A}}$ & $19.92 \pm 0.600^{\mathrm{a}, \mathrm{A}}$ & $20.07 \pm 0.053^{\mathrm{a}, \mathrm{b}, \mathrm{A}}$ \\
\hline 59 & $21.09 \pm 0.201^{\mathrm{b}, \mathrm{A}}$ & $21.08 \pm 0.465^{\mathrm{a}, \mathrm{A}}$ & $21.16 \pm 0.244^{\mathrm{b}, \mathrm{A}}$ \\
\hline
\end{tabular}

Values with different lowercase letters in the same column differ statistically $(\mathrm{p}<0.05)$ Values with different uppercase letters in the same row differ statistically $(\mathrm{p}<0.05)$. P-PP: pigmented polypropylene, LDPE: low-density polyethylene, PP: polypropylene. Source: Authors (2021).

Although some variations of $\mathrm{L}^{*}, \mathrm{a}^{*}$ and $\mathrm{b}^{*}$ were observed in the storage period (there was no significant variation of $b^{*}$ for powdered eggs packaged in LDPE packages), there was no significant difference between the first and the last day of analysis concerning color coordinates. 
The packages did not influence the values of $\mathrm{L}^{*}$ and $\mathrm{b}^{*}$, while for $\mathrm{a}^{*}$, there was only interference from the packaging on the 45th day, being higher in the egg packaged in the PP package compared to the others.

Chudy et al. (2015) reported an oscillatory profile in the luminosity $\left(\mathrm{L}^{*}\right)$ of powdered eggs. The authors used dark storage of the egg powders for 24 months, at $20^{\circ} \mathrm{C}$ and with a maximum $\mathrm{RH}$ of $75 \%$, packaged in polyester and polyethylene bags.

There are several possibilities for the color change of the powdered egg during the storage period. One of them is the Maillard reaction, which occurs due to reducing sugars, even in low concentrations, and protein (Rao \& Labuza, 2012), promoting the non-enzymatic browning of the egg. Another reaction associated with egg browning during storage is lipid oxidation (Chudy et al., 2015). With darkening, therefore, there is a decrease in the value of $\mathrm{L}^{*}$.

In a study carried out by Rao \& Labuza (2012), a relation was observed between the reduction of luminosity in hydrolyzed egg white and the gain in moisture. According to the authors, this fact can be justified by the increase in the motility of the components, with the moisture gain accelerating browning reaction rate. Other points to be considered are the change in light reflection promoted by the absorption of water by powder particles (Rao et al., 2012) and degradation of carotenoids during storage. Wenzel et al. (2011) produced powdered egg yolk by freeze-drying and spray-drying and stored in plastic packages vacuum sealed, in the dark, for 26 weeks. At $20^{\circ} \mathrm{C}$ there was a significant reduction in the lutein and zeaxanthin content, the main carotenoids present in the egg, especially in the first 4 weeks. In addition, these authors also reported that there was isomerization of carotenoids, which may justify changes in $\mathrm{a}^{*}$ and $\mathrm{b}^{*}$ values. Therefore, it is difficult to associate changes in color coordinates during storage with just one reason.

The values obtained for the global color change of freeze-dried eggs from the 59th day concerning the day 0 (zero), for the PP-P, LDPE and PP packages were 3.531, 3.528 and 4.437, respectively, with no significant difference. Therefore, the pigment layer of the P-PP package, did not protect the powder egg against color change.

In a study by Koç et al. (2011b), powdered whole chicken egg produced by spray-drying had a global color change of 1.617 after storage for 180 days, in aluminum laminated polyethylene package, at $20{ }^{\circ} \mathrm{C}$ and $50 \% \mathrm{RH}$. Compared to the values obtained in this study, the smallest global color change may have been due to the lower $\mathrm{RH}$ and the lower storage temperature. This may also indicate a possible greater barrier of packaging used by these authors against water vapor and oxygen. Another factor to be considered is that spray-drying occurs at high temperatures, differently from what happens in freeze-drying, which affects the final color of the powder and consequently the color change throughout the storage.

\subsubsection{Sorption isotherms}

The sorption isotherms describe the behavior of water binding to dried foods and are of great importance to estimate and even promote an increase in the shelf life of these products (Seth et al., 2018).

The isotherm obtained for the freeze-dried quail egg showed a sigmoidal behavior of type II, according to the classification of Brunauer (Rahman, 2009), as can be seen in Figure 1. The same behavior was reported by Koç et al. (2012), for powdered chicken egg produced by spray-drying. 
Figure 1. Sorption isotherm (experimental data) of freeze-dried quail egg and fits of the GAB, BET and Peleg models.

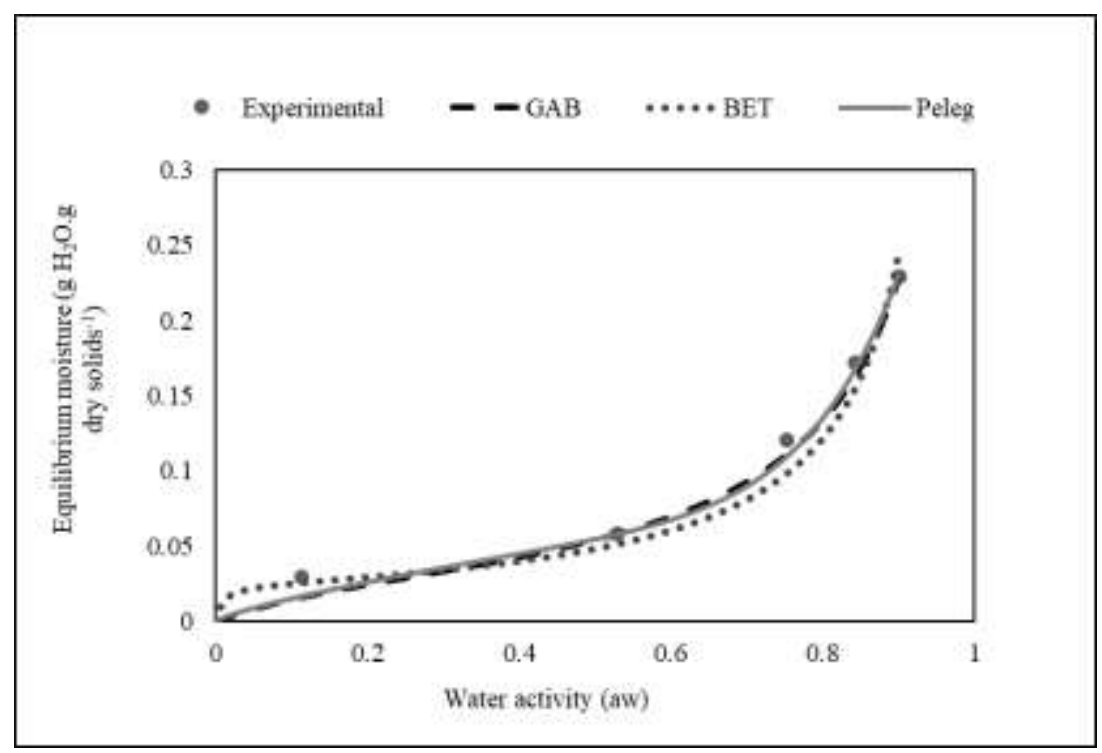

Source: Authors (2021).

The GAB and BET models were the ones that best fit the experimental data since they presented higher values of $\mathrm{R}^{2}$ and adjusted $\mathrm{R}^{2}$ and lower RMSE, as can be seen in Table 7. According to the GAB and BET models, the moisture monolayer contents $\left(\mathrm{X}_{\mathrm{m}}\right)$ for the freeze-dried quail egg were $0.0333 \mathrm{~g} \mathrm{H}_{2} \mathrm{O} / \mathrm{g}$ dry solids $\left(\sim 3.3 \mathrm{~g} \mathrm{H}_{2} \mathrm{O} / \mathrm{g}\right.$ powder$)$ and $0.0227 \mathrm{~g} \mathrm{H}_{2} \mathrm{O} / \mathrm{g}$ dry solids ( 2.2 $\mathrm{g} \mathrm{H}_{2} \mathrm{O} / \mathrm{g}$ powder), respectively.

Table 7. Predicted parameters, coefficient of determination $\left(\mathrm{R}^{2}\right)$ and Root Mean Square Error (RMSE) of the fitted models to the experimental data for moisture sorption isotherm of freeze-dried quail egg.

\begin{tabular}{|c|c|c|c|c|c|c|c|c|c|c|c|}
\hline \multirow{2}{*}{$\mathrm{T}(\mathrm{K})$} & \multirow{2}{*}{ Models } & \multicolumn{7}{|c|}{ Parameters } & \multirow{2}{*}{$\mathrm{R}^{2}$} & \multirow{2}{*}{$\begin{array}{c}\mathrm{R}^{2} \\
\text { (adjusted) }\end{array}$} & \multirow{2}{*}{ RMSE } \\
\hline & & $\mathrm{X}_{\mathrm{m}}$ & $\mathrm{C}$ & $\mathrm{K}$ & $\mathrm{K}_{1}$ & $\mathrm{~K}_{2}$ & $\mathrm{n}_{1}$ & $\mathrm{n}_{2}$ & & & \\
\hline \multirow{3}{*}{298} & GAB & 0.0333 & 6.459 & 0.953 & - & - & - & - & 0.9624 & 0.9197 & 0.02149 \\
\hline & BET & 0.0227 & 111.6 & - & & & & & 0.9229 & 0.9210 & 0.02274 \\
\hline & Peleg & - & - & - & 0.3206 & 0.012 & 7.769 & 0.7809 & 0.9143 & 0.9079 & 0.02301 \\
\hline
\end{tabular}

Source: Authors (2021).

Monolayer moisture refers to the amount of water strongly adsorbed on the particles' surface in the food. It indicates the ideal moisture for a maximum period of shelf life, being, very important for the stability of the product (Rao \& Labuza, 2012; Tonon et al., 2009). Based on $X_{m}$ values found for the two models with better fit, it is proven that the moisture values of the powders during storage were much higher than they should have been, for the product to have a maximum shelf life, especially in the last weeks.

Rao \& Labuza (2012) obtained a good fit of the GAB model for spray-dried hen egg white (mean absolute percentage error $<5 \%$ ), and the $\mathrm{X}_{\mathrm{m}}$ value found was $0.062 \mathrm{~g} \mathrm{H}_{2} \mathrm{O} / \mathrm{g}$ dry solids. Koç et al. (2012), reported values of $0.062 \mathrm{~g} \mathrm{H} \mathrm{H}_{2} \mathrm{O} / \mathrm{g}$ dry solids $\left(\mathrm{R}^{2}=0.982\right.$ and $\left.\mathrm{RMSE}=1.494 \%\right)$ and $0.145 \mathrm{~g} \mathrm{H}_{2} \mathrm{O} / \mathrm{g}$ dry solids $\left(\mathrm{R}^{2}=0.997\right.$ and $\left.\mathrm{RMSE}=2.747 \%\right)$ for adjustments of the BET and GAB, respectively, for spray-dried chicken egg. 


\section{Conclusion}

The powdered quail egg has industrial potential, mainly due to the product nutritional value, and its processing should be further studied. Through this study, it was possible to observe that, despite the good stability in the visual evaluation of freezedried quail eggs, the quail egg powder is susceptible to changes in storage when exposed to the high relative humidity and packaged in bags with a low water barrier. To promote more stable characteristics during the storage of freeze-dried quail eggs in high relative humidity, thicker packages or other strategies (like additives) should be used together to ensure an extension of the shelf life of this nutritionally rich product. The authors suggest for future research, that the stability (including microbiological quality) of powdered quail eggs obtained by freeze-drying, as well as by other drying methods, stored in packages with higher barriers to water permeability and under different conditions of relative humidity and temperature, be evaluated, in order to define packages that promote a longer shelf life for powdered quail eggs, for different experimental conditions.

\section{Acknowledgments}

To Fundação de Apoio Universitário (FAU-UFU), Pró-Reitoria de Pesquisa e Pós-graduação (ProPP-UFU), Coordenação de Aperfeiçoamento de Pessoal de Nível Superior (CAPES), Fundação de Amparo à Pesquisa do Estado de Minas Gerais (FAPEMIG), Conselho Nacional de Desenvolvimento Científico e Tecnológico (CNPq) and Financiadora de Estudos e Projetos (FINEP) for their research incentives and investments and to technicians of the Laboratories of Food Engineering of the Federal University of Uberlandia, Patos de Minas campus for their support.

\section{References}

Arthur, J. \& Bejaei, M. (2017). Quail Eggs. In P. Y. Hester (Ed.). Egg Innovations and Strategies for Improvements (p. 13-21). Academic Press. https://doi.org/10.1016/B978-0-12-800879-9.00002-0

Beck, J., Ledl, F., Sengl, M. \& Severin, T. (1990). Formation of acids, lactones and esters through the Maillard reaction. Zeitschrift für Lebensmittel Untersuchung und Forschung, v. 190 (3), 212-216. 10.1007/bf01192968

Chełmońska, B., Jerysz, A., Łukaszewicz, R., Kowalczyk, A. \& Malecki, I. (2008). Semen collection from Japanese quail (Coturnix japonica) using a teaser female. Turkish Journal of Veterinary and Animal Sciences, 32 (1), 19-24.

Chudy, S., Pikul, J., Rudzińska, M. \& Makowska, A. (2015). The effect of storage on physicochemical properties of spray-dried milk, egg and milk-egg mixture. Acta Agrophysica, v. 22 (1), 17-26.

Conceição, M. C., Fernandes, T. N. \& Resende, J. V. (2016). Stability and microstructure of freeze-dried guava pulp (Psidium guajava L.) with added sucrose and pectin. Journal of Food Science and Technology, 53 (6), 2654-2663. 10.1007/s13197-016-2237-5

Dufour, D., O’Brien, G. M. \& Best, R. (1996). Cassava flour and starch: progress in research and development. Centro Internacional de Agricultura Tropical.

FAO - The Food and Agriculture Organization of the United Nations. (2021). Gateway to poultry production and products: Poultry species. http://www.fao.org/poultry-production-products/production/poultry-species/en/

Fitzpatrick, J. (2013). Powder properties in food production systems. In B. Bhandari et al. (Eds.). Handbook of Food Powders: Processes and Properties. (p. 285-308). Woodhead Publishing. https://doi.org/10.1533/9780857098672.2.285

Gil, A. C. (2008). Métodos e técnicas de pesquisa social (6a ed.). Atlas.

Greenspan, L. (1977). Humidity Fixed Points of Binary Saturated Aqueous Solutions. Physics and Chemistry, 81 A (1), 89-96.

Henríquez, C., Córdova, A., Lutz, M. \& Saavedra, J. (2013). Storage stability test of apple peel powder using two packaging materials: High-density polyethylene and metalized films of high barrier. Industrial Crops and Products, 45, 121-127. http://dx.doi.org/10.1016/j.indcrop.2012.11.032

Instituto Adolfo Lutz. (2008). Normas analíticas do instituto Adolfo Lutz: métodos químicos e físicos para análise de alimentos. Instituto Adolfo Lutz.

Jayaraman, K. S. \& Gupta, D. K. (2006). Drying of Fruits and Vegetables. In A. S. Mujumdar (Ed.). Handbook of Industrial Drying (p. 606-631), 3. ed. CRC Press.

Koç, M., Koç, B., Yilmazer, M. S., Ertekin, F. K., Susyal, G. \& Bağdatlığlu, N. (2011a). Physicochemical Characterization of Whole Egg Powder Microencapsulated by Spray Drying. Drying Technology, 29 (7), 780-788. 10.1080/07373937.2010.538820 
Koç, M., Koç, B., Susyal, G., Yilmazer, M. S., Bağdatlioğlu, N. \& Kaymak-Ertekin, F. (2011b). Improving Functionality of Whole Egg Powder by the Addition of Gelatine, Lactose, and Pullulan. Journal of Food Science, 76 (9). 10.1111/j.1750-3841.2011.02420.x

Koç, B., Koç, M., Güngör, O., Sakin-Yilmazer, M., Kaymak-Ertekin, F., Susyal, G. \& Bağdatlioğlu, N. (2012). Effects of Formulation on Stability of Spray Dried Egg. Drying Technology, v. 30 (1), 63-71. 10.1080/07373937.2011.620202

Köche, J. C. (2011). Fundamentos de metodologia científica: teoria da ciência e iniciação à pesquisa. Vozes.

Lechevalier, V., Nau, F., \& Jeantet, R. (2013). Powdered egg. In B. Bhandari et al. (Eds.). Handbook of Food Powders: Processes and Properties (p. 484-512). Woodhead Publishing. https://doi.org/10.1533/9780857098672.3.484

Lieu, Eng-Hwa, Froning, G. W. \& Dam, R. (1978). Effect of Storage on Lipid Composition and Functional Properties of Dried Egg Products. Poultry Science, v. 57, 912-923. https://doi.org/10.3382/ps.0570912

Martins, S. I. F. S., Jongen, W. M. F. \& Boekel, M. A. J. S. (2000). A review of Maillard reaction in food and implications to kinetic modelling. Trends in Food Science \& Technology, v. 11 (9-10), 364-373. https://doi.org/10.1016/S0924-2244(01)00022-X

Moura, A. M. A., Oliveira, N. T. E., Thiebaut, J. T. L. \& Melo, T. V. (2008). Effect of storage temperature and type of package on the internal quality of eggs from japanese quails (Coturnix japonica). Ciência e Agrotecnologia, 32 (2), 578-583.

Oliveira, D. M., Lima, C. G., Clemente, E., Afonso, M. R. A. \& Costa, J. M. C. (2015). Stability of bioactive compounds and quality parameters of grugru palm powder (Acrocomia aculeata) in different drying conditions. Journal of Food Quality, 38, 94-102. 10.1111/jfq.12126

Ortiz, C. M., Moraes, J. O., Vicente, A. R., Laurindo, J. B. \& Mauri, A. N. (2017). Scale-up of the production of soy (Glycine max L.) protein films using tape casting: Formulation of film-forming suspension and drying conditions. Food Hydrocolloids, v. 66, 110-117. https://doi.org/10.1016/j.foodhyd.2016.12.029

Pereira, A. S., Shitsuka, D. M., Parreira, F. J. \& Shitsuka, R. (2018). Metodologia da pesquisa científica UFSM. https://repositorio.ufsm.br/bitstream/handle /1/15824/Lic_Computacao_Metodologia-Pesquisa-Cientifica.pdf?sequence=1

Rahman, M. S. (2009). Food properties handbook. (2a ed.) CRC Press.

Raitio, R., Orlien, \& Skibsted, L. H. (2011). Storage stability of cauliflower soup powder: The effect of lipid oxidation and protein degradation reactions. Food Chemistry, 128, 371-379. 10.1016/j.foodchem.2011.03.038

Rao, Q. \& Labuza, T. P. (2012). Effect of moisture content on selected physicochemical properties of two commercial hen egg white powders. Food Chemistry, 132, 373-384. 10.1016/j.foodchem.2011.10.107

Rao, Q., Rocca-Smith, J. R., Schoenfuss, T. C. \& Labuza, T. P. (2012). Accelerated shelf-life testing of quality loss for a commercial hydrolysed hen egg white powder. Food Chemistry, 135, 464-472. http://dx.doi.org/10.1016/j.foodchem.2012.05.025

Sangamithra, A., Venkatachalam, S., John, S. G. \& Kuppuswamy, K. (2014). Foam mat drying of food materials: a review. Journal of Food Processing and Preservation. https://doi.org/10.1111/jfpp.12421

Seth, D., Dash, K. K., Mishra, H. N. \& Deka, S. C. (2018). Thermodynamics of sorption isotherms and storage stability of spray dried sweetened yoghurt powder. Journal of Food Science and Technology, 55 (10), 4139-4147. https://doi.org/10.1007/s13197-018-3340-6

Shanaway, M. M. (1994). Quail production systems: a review. FAO.

Sokhansanj, S. \& Jayas, D. S. (2006). Drying of Foodstuffs. In A. S. Mujumdar (Ed.). Handbook of Industrial Drying (p. 522-5453), 3. ed. CRC Press.

Sun, C., Liu, J., Yang, N. \& Xu, G. (2019). Egg quality and egg albumen property of domestic hen, duck, goose, turkey, quail, and pigeon. Poultry Science, 98 (10), 4516-4521. https://doi.org/10.3382/ps/pez259

Thélie, A., Grasseau, I., Grimaud-Jottreau, I., Seigneurin, F. \& Blesbois, E. (2019). Semen biotechnology optimization for successful fertilization in Japanese quail (Coturnix japonica). Theriogenology, 139, 98-105. https://doi.org/10.1016/j.theriogenology.2019.07.028

Tonon, R. , Brabet, C. \& Hubinger, M. D. (2008). Influence of process conditions on the physicochemical properties of açai (Euterpe oleraceae Mart.) powder produced by spray drying. Journal of Food Engineering, 88 (3), 41-418. https://doi.org/10.1016/j.jfoodeng.2008.02.029

Tonon, R. , Baroni, A. F., Brabet, C., Gibert, O., Pallet, D. \& Hubinger, M. D. (2009). Water sorption and glass transition temperature of spray dried açaí (Euterpe oleracea Mart.) juice. Journal of Food Engineering, 94, 215-221. 10.1016/j.jfoodeng.2009.03.009

Udomkun, P., Nagle, M., Argyropoulos, D., Mahayothee, B, Latif, S. \& Müller, J. (2016). Compositional and functional dynamics of dried papaya as affected by storage time and packaging material. Food Chemistry, 196, 712-719. http://dx.doi.org/10.1016/j.foodchem.2015.09.103

USDA - United States Department of Agriculture. (2021a). FoodData Central Search Results: Egg, quail, whole, fresh, raw. https://fdc.nal.usda.gov/fdcapp.html\#/food-details/172191/nutrients

USDA - United States Department of Agriculture. (2021b). FoodData Central Search Results: Egg, whole, raw, fresh. https://fdc.nal.usda.gov/fdcapp.html\#/food-details/171287/nutrients 
Research, Society and Development, v. 10, n. 14, e184101420930, 2021

(CC BY 4.0) | ISSN 2525-3409 | DOI: http://dx.doi.org/10.33448/rsd-v10i14.20930

Velioğlu, S. D. (2019). Determination of the foaming and emulsifying properties of lyophilized whole quail egg, egg yolk and egg White. GIDA The Journal of Food, 44 (5), 919-931. 10.15237/gida.GD19113

Vilela, D. R., Carvalho, L. S. S., Fagundes, N. S. \& Fernandes, E. A. (2016). Qualidade interna e externa de ovos de poedeiras Comerciais com cascas normal e vítrea. Ciência Animal Brasileira, 17 (4), 509-518. 10.1590/1089-6891v17i421535

Wenzel, M., Seuss-Baum, I. \& Schlich, E. (2011). Influences of storage time and temperature on the xanthophyll contente of freeze-dried egg yolk. Food Chemistry, 124, 1343-1348. 10.1016/j.foodchem.2010.07.085 